\title{
An Estimation of Dynamic Modulus of Elasticity in Cantilever Flexural Timber Beams
}

\section{Određivanje dinamičkog modula elastičnosti drvenih konzola}

\author{
Original scientific paper • Izvorni znanstveni rad \\ Received-prispjelo: 28. 6. 2012. \\ Accepted-prihvaćeno: 6. 2. 2014. \\ UDK: $630 * 812.7 ; 630 * 833$ \\ doi:10.5552/drind.2014.1229
}

\begin{abstract}
Due to considerable influence of shear deflection and rotary motion, the modulus of elasticity is hardly obtainable in fixed-free flexurally-excited (cantilever) beams. For isotropic materials, Timoshenko has proposed a set of curves to correct the fixed-free modal frequencies as the radius of gyration and free length; however, its performance for wood was not sufficiently conclusive. In this study, rectangular beams of pine wood were tested in a fixed-free condition, altering the free length to height ratios in a proper extent and comparing them to their reference free-free data in terms of natural frequency and dynamic modulus of elasticity shifts. The equality of two pairs of fixed-free versus free-free data, for both frequency and dynamic modulus, was significantly confirmed. The correlation coefficient between experimental and calculated fixed-free frequencies was high enough, and however the correlation coefficient of the modulus of elasticity was rather low.
\end{abstract}

Keywords: assessment, cantilever beam, flexural, nondestructive technique (NDT), Timoshenko, vibration, wood

SAŽETAK • Zbog utjecaja otklona smicanjem i rotacijskog pomaka vrlo je teško odrediti modul elastičnosti konzolnih greda opterééenih na savijanje. Za izotropne materijale Timošenko je predložio skup korekcijskih krivulja za modalne frekvencije konzolnih uzoraka u ovisnosti o radijusu otklona i duljini slobodnog kraka. Međutim, njihova preciznost za drvo nije bila zadovoljavajuća. U prikazanom istraživanju analizirana su svojstva konzolnih greda od borovine pri promjeni omjera slobodne duljine $i$ visine grede u odgovarajućoj mjeri i u usporedbi s prirodnom frekvencijom i dinamičkim modulom elastičnosti slobodne grede. Rezultati istraživanja pokazali su da ne postoji statistički značajna razlika u frekvenciji i dinamičkome modulu elastičnosti između ispitivanih uzoraka u svojstvu slobodnih greda i onih koji služe kao konzole. Koeficijent korelacije između eksperimentalne i proračunske frekvencije za konzole bio je vrlo visok, iako je za isti primjer konzole koeficijent korelacije za dinamički modul elastičnosti bio vrlo malen.

Ključne riječi: procjena, konzole, savijanje, nedestruktivno ispitivanje (NDT), Timošenko, vibracije, drvo

\footnotetext{
${ }^{1}$ Author is associate professor at Department of Wood and Paper Science and Technology, Karaj Branch, Islamic Azad University, Karaj-Iran.

${ }^{1}$ Autor je izvanredni profesor Odjela za znanost i tehnologiju drva i papira, Karaj Branch, Islamsko sveučilište Azad, Karaj-Iran.
} 


\section{INTRODUCTION}

\section{UVOD}

By definition, a cantilever beam is a beam having one end rigidly fixed, thus preventing any displacement and rotation at the supported end, whereas the other end is free to deform. Due to shear deflection and rotary motion, the modulus of elasticity is hardly obtainable in fixed-free flexurally-excited (cantilever) beams. The present study was made on the basis of a study on fixed-free timber beams done by Shafiee (2010) and Roohnia et al. (2011b. Meanwhile, the initial experience in isotropic elasticity was considered quite promising.

With isotropic materials, a large number of studies have been conducted to explain the dynamic characteristics of beam structures (Gurgoze and Batan, 1986; Jang and Bert, 1989; Rossi and Laura, 1990; Farghaly, 1992; Auciello, 1996; Banerjee, 1999; Lee, 2009). Negahban (1999) examined the deflection, frequency and practical uses of cantilever beams under vibration. He demonstrated that if a beam was covered by a thin film, the flexural rigidity altered. The subsequent changes affected the vibration frequency shift. In this case, if the frequency shift was measured, the film elastic modulus could be calculated. Yu (2009) studied free and forced flexural vibration analysis of cantilever plates with attached point mass. He investigated the effects of mass ratios and locations of the point mass on Eigen values and modal participation factors for square and rectangular plates. Similarly, Alzaharnah (2009) considered the flexural characteristics of a cantilever plate heated from the fixed end. Caruntu (2009) was concerned with free transverse vibrations of non-uniform homogeneous beams, while Chondros and Dimarogonas (1998) analyzed the vibration of a cracked beam. Damages and cracks were also studied by Leonard et al. (2001), Radhakrishnan (2004), Orhan (2007), Il'gamov and Khakimov (2009) and Roohnia et al. (2010, 2011a).

Longitudinal dynamic modulus of elasticity, as the most important mechanical characteristic of timber rectangular beams, could be evaluated through several vibration methods such as free or forced, flexural or longitudinal vibration of a beam in several supporting conditions (Bodig and Jayne, 1993). A real free-free condition (if possible) might be more favorable as a reference method due to lack of any effects from supports to the vibration of the beam. In wood science, natural vibration analysis is often used to characterize the longitudinal and shear modulus of elasticity in various geometrical types of prismatic beams. Free vibration of a free-free beam was deeply discussed by Brancheriau and Bailleres (2002), who considered a broad range of theories and different directions of vibration. A lateral or axial percussion at one end of the beam set up on elastic support produces flexural or longitudinal vibrations. Formulating a hypothesis for homogeneity of geometrical and mechanical properties of the beam, the basic dynamics theorem can be applied to obtain the motion equations of longitudinal and transverse vibrations. The resolution of the differential equation for transverse motion leads to the search for solutions to the frequency equation (Brancheriau and Bailleres, 2002). Since there are no exact analytical solutions, they analyzed several approximate approaches. In their report, the effects of the elastic supports, the shear modulus and the height to length ratio were discussed. They presented the most common theoretical models and defined their validity range, application conditions, and accuracy levels with respect to measured values.

As the position of a member in a timber structure varies largely relative to its end supports, solving the vibration equations for the above-mentioned support conditions would be satisfactory, since extracting these members for carrying out a free-free test would be especially harmful to an old structure. The vibration equations, therefore, should be developed based on their original position or by in-situ examinations. This study of free flexural vibrations in a cantilever beam was a continuation of previous research (Shafiee, 2010; Roohnia et al., 2011b) that rarely dealt with timber beams in literature.

To determine the relative magnitude of shear deflection in terms of an idealized solution, Timoshenko defined a correction factor as the radius of gyration divided by free length in which the correction coefficient depended upon the ratio of specimen thickness to specimen length (Harris, 2002; Turk et al., 2008). Timoshenko presented a set of curves to determine the correction factor in six initial modes of flexural vibration. Its performance for wood with different dynamic responses in LR and LT flexural vibrations (where LT and LR correspond to the relative plane of flexure) was, however, not sufficiently conclusive (Roohnia et al., 2011b). In 2008, Turk et al. did not compare the obtained moduli of elasticity through vibration of fixed-free beams with any other certified method but found it applicable for orthotropic materials such as wood considering the repeatability of the testing procedure. A comparative study of flexural vibration of fixed-free and free-free beams, with no correction algorithm for shear deflection, rotary motion or any other unverified potential confusion, was done with absolutely clear timber beams of similar dimensions (Shafiee, 2010; Roohnia et al., 2011b). The aim of this article was to find a frequency correction method for cantilever timber beams other than the one proposed byTimoshenko

\section{MATERIALS AND METHODS}

\section{MATERIJALI I METODE}

\subsection{Theories}

2.1. Teorije

Based on Euler-Bernoulli's elementary equations of bending, the dynamic flexural modulus of elasticity of a beam is evaluated under flexural free or forced free vibration as follows: 


$$
\left(\frac{E_{d}}{\rho}\right)_{n}=\left[\frac{4 \cdot \pi^{2} \cdot l^{2} \cdot f_{n}^{2}}{\alpha \cdot m_{n}^{4}}\right]
$$

where, $E_{d}$ is dynamic modulus of elasticity $(\mathrm{Pa}), \rho$ is stabilized density $\left(\mathrm{kg} \cdot \mathrm{m}^{-3}\right), n$ is mode number, $l$ is free length $(\mathrm{m}), f_{n}$ is frequency of $n^{\text {th }}$ mode $(\mathrm{Hz}), m_{n}$ is a constant related to support condition and mode number (for the fundamental frequency, $m_{1}$ is equal to 4.73 for a free-free condition and 1.785 for a fixed-free condition; Bodig and Jayne 1993). $\alpha$ is the square value of gyration radius divided by free length, equation (2)

$$
\alpha=\left(\frac{\sqrt{I / A}}{l}\right)^{2}=\frac{I}{A \cdot l^{2}}
$$

Equation (1) is an idealized equation of vibration that neglects the effects of shear force and rotary motion in the specimen. However, the application of this equation is limited to some proper $l / h$ ratios (greater than 20 in a free-free condition or greater than 58 in a fixed-free condition). To determine the relative magnitude of shear force in terms of the idealized solution in a fixed-free isotropic beam, Timoshenko introduced a set of curves to obtain the correction factor defined by the radius of gyration and free length (Harris, 2002; Turk et al., 2008) (Fig. 1).

Therefore, if care is taken to control the ratio of thickness divided by free length, the radius of gyration divided by free length (Equation (2)) is $<0.005$ (dimensionless), and the frequency correction factor approaches 1.0 where shear and rotary effects are negligible (Turk et al., 2008).

The flexural dynamic modulus of elasticity is also evaluated using Timoshenko's theory of bending (an improvement for Euler-Bernoulli's elementary the-

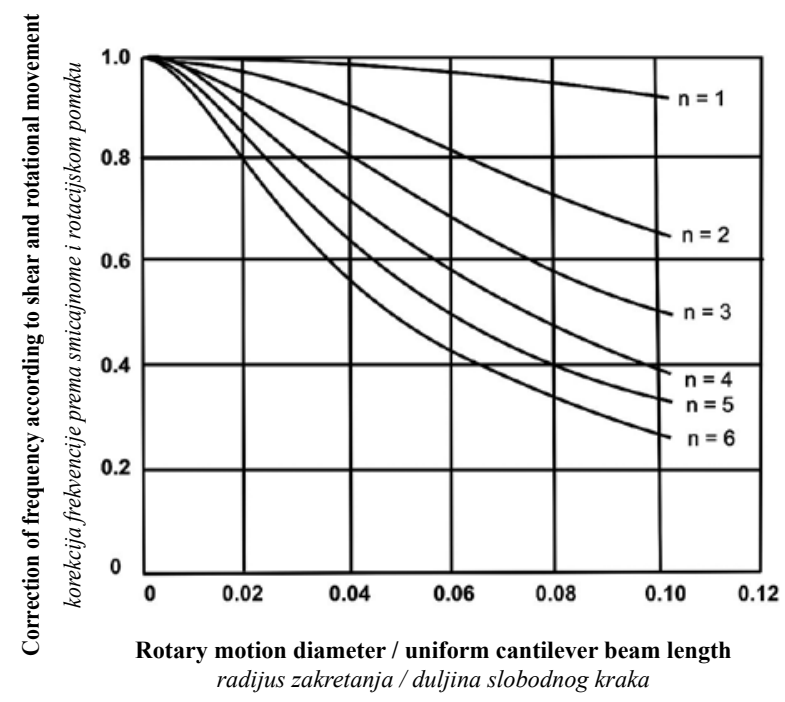

Figure 1 Influence of shear force and rotary motion on natural frequencies of uniform cantilever beams; $n$ is mode number (Harris, 2002)

Slika 1. Utjecaj sile smicanja i rotacijskoga gibanja na prirodnu frekvenciju uniformiranih uzoraka konzola; $n$ je broj modova (Harris, 2002) ory of bending), fitting a trend line among three or more points with the coordinates of $\left(x_{n}, y_{n}\right), \mathrm{n}=1,2,3$, ..., calculated from three or more initial modes of flexural free-free vibration considering a proper correlation coefficient, R. The intercept in Timoshenko's trend line is a specific modulus and its slope is the ratio of modulus of elasticity to the shear modulus (Bordonné, 1989; Brancheriau and Bailleres, 2002; Roohnia et al., 2006, 2010) (Equation (3)):

$$
\mathrm{y}=\left(\frac{E_{d}}{\rho}\right)-\left(\frac{E_{d}}{K \times G_{i j}}\right) \cdot x, R^{2}>0.99
$$

where, $K$ is shape coefficient (the value of $5 / 6$ can be used for a rectangular cross section and 0.9 for round cross sections; Harris, 2002) and $G_{i j}$ is shear modulus in vibration plane $\left(G_{L T}\right.$ or $\left.G_{L R}\right)$.

Higher correlation coefficients of the estimated trend lines in Equation (3) produce homogenous specimens, where the Timoshenko's theory has been fitted initially to isotropic materials. Decreasing the isotropic behavior would result in lower correlation coefficients. It is obvious that wood defects would decrease its axial isotropic (orthotropic) characteristics.

\subsection{Experiments \\ 2.2. Eksperimenti}

Free vibration of a free-free bar, a method for evaluating the dynamic modulus of elasticity of clear timber elements with an acceptable deviation (10-15 $\%$ ), compared to that of standard static bending has been confirmed analytically and experimentally in literature (Bodig and Jayne, 1993; Cai et al., 2000, Brancheriau and Bailleres, 2002; Yang et al., 2002; Divos and Tanaka, 2005; Liang and Fu, 2007, Madhoushi et al., 2008, Roohnia and Tajdini, 2008). Accordingly, this method could be used to obtain the reference values of modulus of elasticity.

For starting the experiments, 20 pieces of visually clear rectangular beams with the dimensions of $50 \times 20 \times 500 \mathrm{~mm}$ (width $\times$ height $\times$ length) $($ RTL) were prepared in accordance with ISO 3129 , from a visually graded pine lumber. The specimens were dried softly at $60{ }^{\circ} \mathrm{C}$ for 72 hours, and conditioned in a climatic chamber at the relative humidity of $65 \%$ and temperature of $20{ }^{\circ} \mathrm{C}$ for a few weeks until the moisture contents were stabilized (conditioning started from zero point). Based on Bordonné's solution for Timoshenko's theory of bending (Bordonné, 1989), and considering Timoshenko's correlation coefficients higher than $0.99,16$ out of 20 measurements were accepted as the selected samples to be taken into account for further analysis.

A total of 16 reference dynamic flexural modulus of elasticity values were selected for 16 specimens, and evaluated in free flexural vibration of free-free beams, where Bernoulli's elementary theory was used for elasticity evaluations. Equation (1) was solved for natural frequency of fixed-free beams where the reference free-free modulus was used: 


$$
f_{c}=\left(\frac{\alpha \cdot 1.875^{4} \cdot E_{d}}{4 \cdot \pi^{2} \cdot l^{2} \cdot \rho}\right)^{\frac{1}{2}}
$$

where, $f_{c}$ is the calculated fundamental frequency in fixed-free condition.

Experimental frequency of the fundamental mode, $f_{e}$, was evaluated in fixed-free condition (Fig. 2), while altering the free length, stepwise from $l=0.96 \cdot L$ to 0.88 $\cdot L, 0.8 \cdot L, 0.72 \cdot L, 0.64 \cdot L$ and $0.56 \cdot L(48,44,40,36$, 32 and $28 \mathrm{~cm}$, respectively), and relative shifts of fixedfree fundamental frequencies were evaluated in Equation (5). The gripping compression was kept constant at the fixed ends using a proper torque wrench.

$$
f_{s h}=\frac{f_{c}-f_{e}}{f_{c}} \times 100
$$

where, $f_{\mathrm{sh}}$ is the relative shift of frequency (\%) defined as a function of experimental frequency $f_{e}$ and calculated fundamental frequency $f_{c}$.

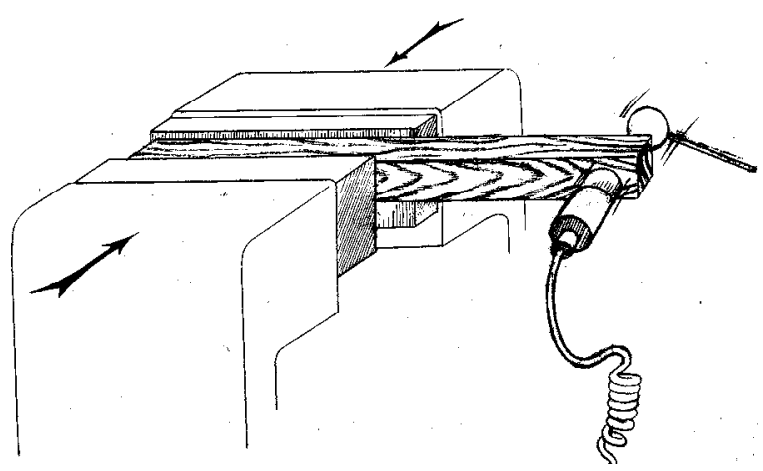

Figure 2 Schematic view of the setup for free flexural vibration of a fixed-free bar test. Sound recording and hammer impact at free end of the bar

Slika 2. Shematski prikaz uzorka pričvršćenoga u konzolu za određivanje vibracije savijanja. Pobuđivanje uzorka i mjerenje zvuka obavljeni su na kraju slobodnog kraka konzole

The specimen heights decreased stepwise from 20 to $18,16,14,12,10$ and 8 millimeters and the above-mentioned evaluations were replicated thoroughly.

The gyration radius was divided into free lengths and correlated with the frequency radius corrected for shear and rotary motion, obtained from calculated frequency shifts and compared to the Timoshenko's correction curve (Fig. 1, $n=1$ ).

Apart from Timoshenko's correction, another equation was proposed to predict the frequency shifts in terms of free length $(l)$ and height $(h)$ of the beams (to compensate the effects of shear deflection and rotary motion). Then, the dynamic flexural moduli of the specimens were evaluated using recalculated frequen- cies of fixed-free beams before being compared to previous reference moduli of free-free flexural vibration.

\section{RESULTS AND DISCUSSION}

\section{REZULTATI I DISKUSIJA}

Frequencies corrected for shear and rotary motion obtained from the calculated frequency shifts were plotted as the radii of gyrations divided into free lengths in Fig. 3.

Comparison between the fitted curve in this particular study (Fig. 3) and Timoshenko's correction curve (Fig. 1, $n=1$ ) shows some similarities and differences. The studied interval was too limited to reject Timoshenko's correction method for this particular timber material. However, it should be noted that, as shown in Fig. 3, when the root of Equation (2) decreased to smaller values $(\sqrt{\alpha}<0.005)$, the frequency correction factor hardly approached 1.0. So, the effects of shear force and rotary motion were not compensated yet. So, the Timoshenko's correction curves were proposed based on the dynamic behavior of isotropic materials, for example, steel, aluminum or magnesium (Harris 2002). However, some deviations from this proposition could be initially expected for an anisotropic/orthotropic material.

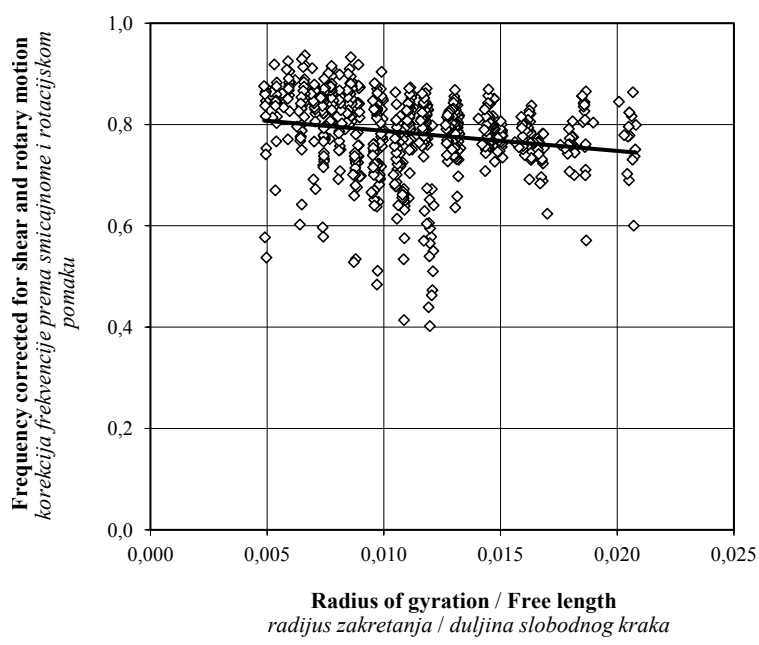

Figure 3 Fundamental $(n=1)$ frequency corrected for shear and rotary motion versus radius of gyration divided by free length $\left(\alpha^{0.5}\right)$ in studied fixed-free specimens

Slika 3. Prirodna $(n=1)$ frekvencija korigirana prema smicajnome i rotacijskom pomaku u ovisnosti o kvocijentu radijusa okretanja i duljini slobodnog kraka uzorka konzole

To propose an equation to compensate for the effects of shear deflection and rotary motion (in terms of free length, $l$, and height, $h$, of the beams), other than Timoshenko's correction proposition, the frequency shifts were plotted against $l / h$ ratios in Fig. 4. The correlation was statistically significant at $p$-value $<0.01$ despite a low $R^{2}$. Frequency shifts decreased with increases in $l / h$ ratio. 


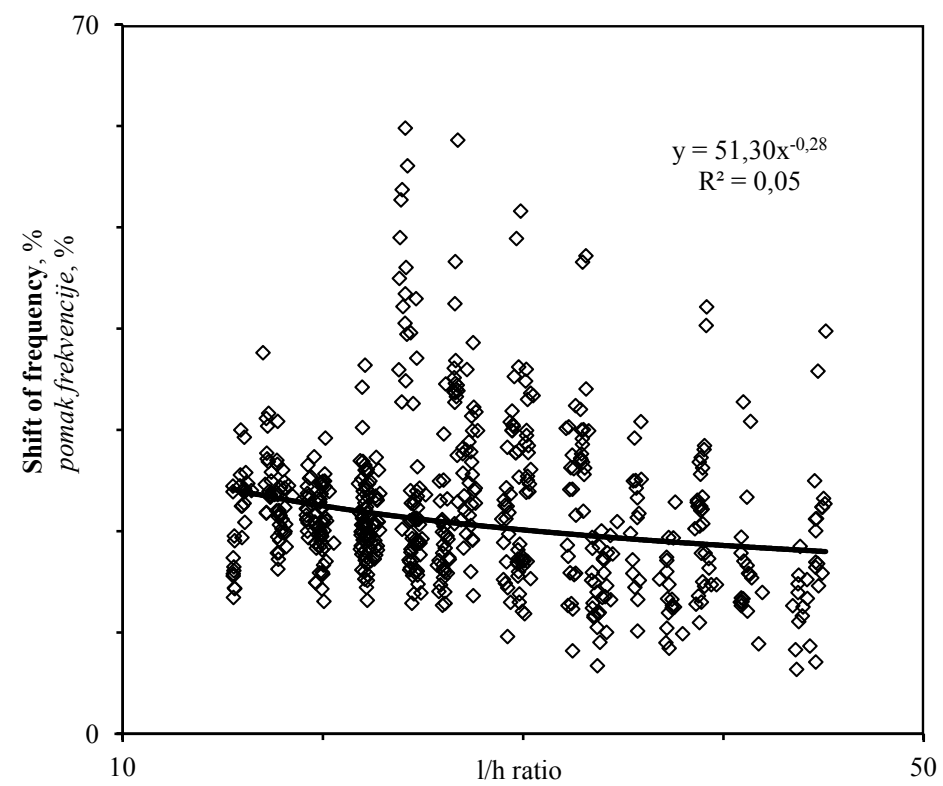

Figure 4 Frequency shifts versus $l / h$ ratio of specimens in the stepwise scenario

Slika 4. Pomak frekvencije u odnosu prema kvocijentu duljine slobodnog kraka i visine uzorka $(l / h)$

To check the properties of the fitted curve, the recalculated fundamental frequency of fixed-free data, $f_{r e}(\mathrm{~Hz})$, was obtained from experimental frequency, $f_{e}$ $(\mathrm{Hz})$, and recalculated frequency shifts, $f_{\text {resh }}(\%)$, by Equations (6) and (7).

$$
\begin{gathered}
f_{\text {resh }}=51.3 \cdot\left(\frac{l}{h}\right)^{-0.28} \\
f_{r e}=\frac{f_{e}}{1-f_{\text {resh }}}
\end{gathered}
$$

Recalculated frequencies in fixed-free conditions versus initially calculated fixed-free values from reference free-free data, $f_{c}$, are plotted in Fig. 5. This equality of the data calculated from reference and experimental values with highly powerful correlation coefficient implies that the estimated curve equation can be applied to compensate for the effects of shear deflection and rotary motion. The evaluated correlation coefficient was statistically significant (at $p<0.01)$ in cases when the equality of the vertical and horizontal data was confirmed by $t$-test as well as when these data were seen in trend line equation (Fig. 5).

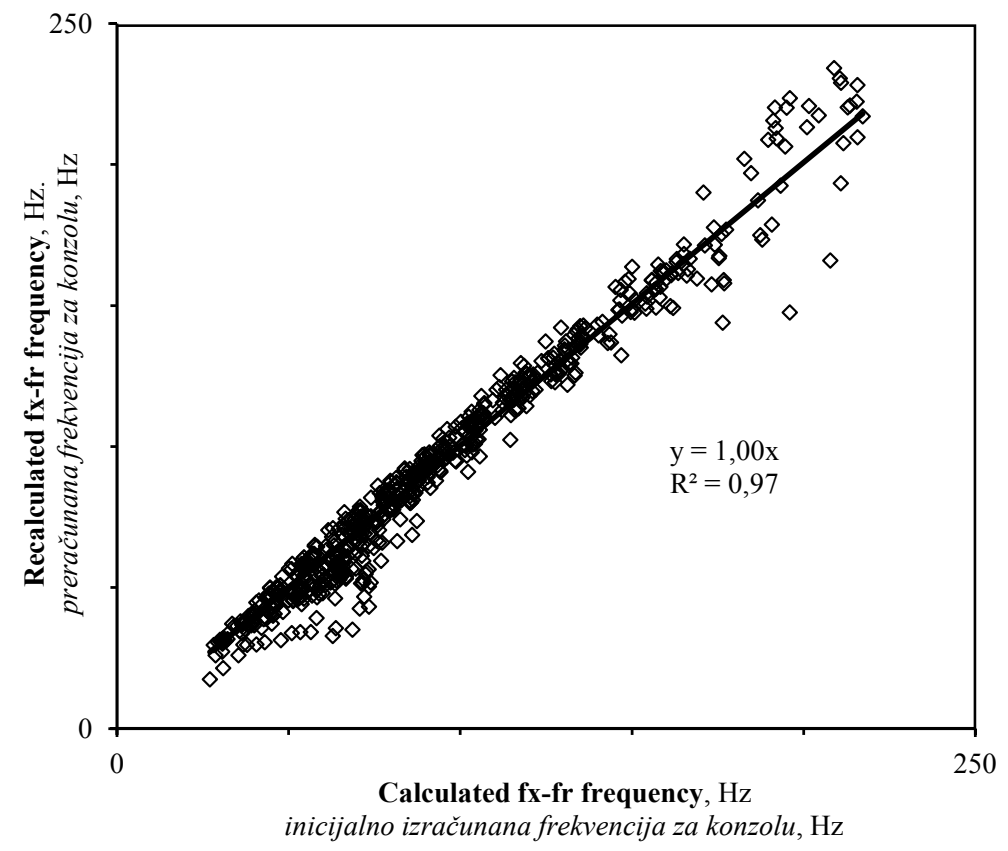

Figure 5 Recalculated frequencies versus innitially calculated frequencies in fixed-free condition Slika 5. Odnos preračunane frekvencije i inicijalno izračunane frekvencije za sustav konzole 


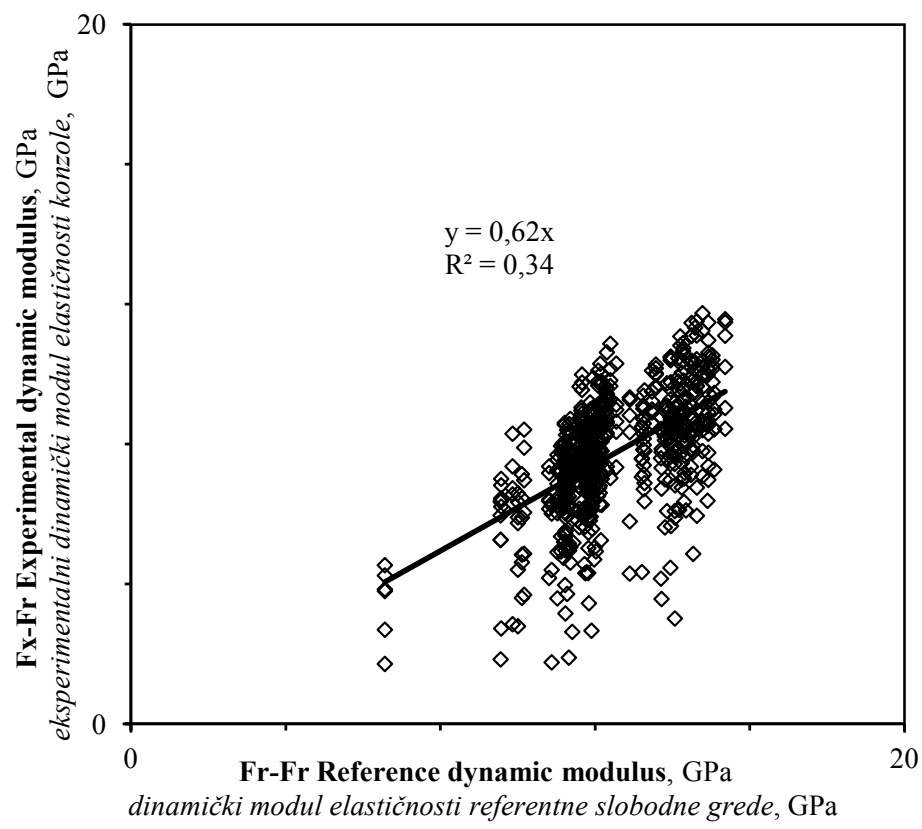

Figure 6 Experimental unmodified fixed-free versus reference free-free dynamic modulus

Slika 6. Odnos eksperimentalnoga dinamičkog modula elastičnosti između nepromijenjene konzole i referentne slobodne grede

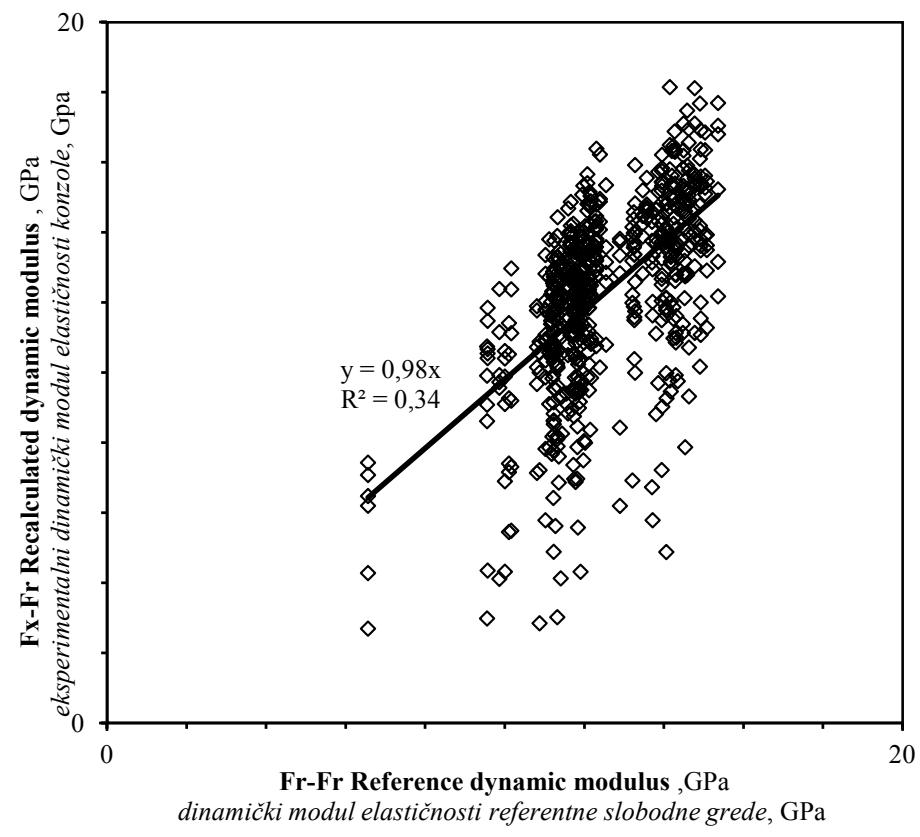

Figure 7 Recalculated fixed-free versus refernce free-free dynamic modulus

Slika 7. Odnos preračunanoga dinamičkog modula elastičnosti konzole i inicijalnog modula elastičnosti slobodne grede

The potential for modification of fixed-free frequency made in Equation (6) would be a significant advancement if it could estimate the dynamic modulus of elasticity as accurately as the reference free-free data. Due to inevitable uncertainties in wood, the correlation coefficient between raw unmodified fixed-free and reference free-free moduli was initially insignificant. However, fortunately, it was statistically significant even at $p<0.01$ (Fig. 6). So, the fixed-free bar in a wide range of $l / h$ ratios, with a correction coefficient, enables us to estimate the actual dynamic modulus of elasticity of wood. This correction coefficient might be the one given by Equations (6) and (7), which was applied to experimental fixed-free raw data.
The unmodified experimental moduli in fixedfree condition versus refernce free-free dynamic modulus of elasticity values in this particular study are plotted in Fig. 7. The fixed-free beam for the proposed correction method and Timoshenko's proposition alike were successful in estimating the actual dynamic modules of elasticity, in cases when the equality of the vertical and horizontal axis data was confirmed by t-test; however, the fitted trend line showed this equality. The correlation coefficient was almost low but significantly equal to initial observations of raw and unmodified data. So, the proposed modification method rarely affected the validity of the natural and inherent correlations. 


\section{CONCLUSION}

\section{ZAKLJUČAK}

Considerable influence caused by shear deflection and rotary motion in fixed-free flexural vibration make the modulus of elasticity hardly obtainable in flexurally-excited beams with similar boundary conditions. Timoshenko proposed a set of curves to correct the fixed-free modal frequency in terms of radius of gyration and free length for isotropic materials such as steel, aluminum or magnesium. A new correction method was proposed and evaluated for timber fixedfree beams with a proper variety of $l / h$ ratios. It was concluded that for fixed-free flexural beams the following applied:

- The effect of shear deflection and rotary motion for fixed-free timber beams decreased as $l / h$ ratios increased, although it would hardly be noticeable, even in some $l / h$ ratios larger than 56 .

- Shift of natural frequency of a timber rectangular fixed-free beam in flexural vibration could be evaluated by Equation (6), where the $l / h$ ratios ranging from 14 to 59 were tested for suitability.

- The correlation coefficient between experimental and calculated fixed-free frequency was very high (0.97) but the correlation coefficient of experimental and calculated modulus of elasticity values was a bit lower (due to lots of uncertainties related to wood); however, their equality was significantly confirmed even at $p$-value $<0.01$. The researcher, therefore, decided to call it an "estimation" of dynamic modulus of elasticity in fixed-free flexural vibration. It would be replaced with "evaluation" when obtaining more evidence from further studies.

- For future studies, it is suggested to extend the frequency correction method to ring-porous and diffuse-porous hardwoods with somewhat different beam dimensions, from ice-cream size to the usual commercial timber cross sections.

\section{Acknowledgements - Zahvale}

This article was extracted from a project conducted by the researcher, entitled 'Designing NDT system of free vibration of a cantilever beam applicable to wood and wood composites in comparison with previous Forced and Free vibration of a Free-Free beam ndt system. I would like to extend special thanks to the Islamic Azad University, Karaj Branch for providing the experimental facilities for this study. My special thanks are dedicated to Navid and Negin Manouchehri, Abdolsaber Yaghmaeipour and Mohammadreza Ghaznavi from www.ndtiranian.ir scientific based group for their assistance with the MATLAB $®$ programming and experimental procedures. My sincere thanks go to Dr. Natasha Q. Pourdana, the CamTESOL international editor, for her attempts in proofreading the initial draft of this article.

\section{REFERENCES}

\section{LITERATURA}

1. Alzaharnah, I. T., 2009: Flexural characteristics of a cantilever plate subjected to heating at fixed end. Journal of Mechanics, 25(1): 1-8. http://dx.doi.org/10.1017/ S1727719100003543.

2. Auciello, N. M., 1996: Transverse vibrations of a linearly tapered cantilever beam with tip mass of rotary inertia and eccentricity. Journal of Sound and Vibration, 194(1): 25-34. http://dx.doi.org/10.1006/jsvi.1996.0341

3. Banerjee, J. R., 1999: Explicit frequency equation and mode shapes of a cantilever beam coupled in bending and torsion." Journal of Sound and Vibration, 224(2): 267-281. http://dx.doi.org/10.1006/jsvi.1999.2194

4. Bodig, J.; Jayne, B., 1993: Mechanics of Wood and Wood Composites. (Persian Trans.) by Ebrahimi G. University of Tehran Press, $686 \mathrm{pp}$.

5. Bordonné, P. A., 1989: Module dynamique et frottement intérieur dans le bois: Mesures sur poutres flottantes en vibrations naturelles Thèse de doctorat de l'INP de Lorraine soutenue à Nancy. $154 \mathrm{p}$.

6. Brancheriau, L.; Bailleres, H., 2002: Natural vibration analysis of clear wooden beams: a theoretical review. Wood Science and Technology, 36: 347-365. http:// dx.doi.org/10.1007/s00226-002-0143-7

7. Cai, Z.; Hunt, M.; Ross, R.; Soltis, L. 2000: Static and vibration moduli of elasticity of salvaged and new joists. Forest products Journal. 50(2): 35-40. http://www.fpl. fs.fed.us/documnts/pdf2000/cai00a.pdf (Accessed July, $\left.12^{\text {th }}, 2013\right)$

8. Caruntu, D. I., 2009: Dynamic modal characteristics of transverse vibrations of cantilevers of parabolic thickness. Mechanics Research Communications, 36: 391404.http://dx.doi.org/10.1016/j.mechrescom.2008.07.005

9. Chondros, T. G.; Dimarogonas, A. D., 1998: Vibration of a cracked cantilever. Transactions of ASME, 120: 742746. http://dx.doi.org/10.1115/1.2893892

10. Farghaly, S. H., 1992: Bending vibration of an axially loaded cantilever beam with an elastically mounted end mass of finite length. Journal of Sound and Vibration, 156: $\quad 373-380 . \quad \mathrm{http}: / / \mathrm{dx}$.doi.org/10.1016/0022460X(92)90706-4

11. Gugoze, M.; Batan, H., 1986: A note on the vibrations of a restrained cantilever beam carrying a heavy tip body. Journal of Sound and Vibration, 106:533-536. http://dx. doi.org/10.1016/0022-460X(86)90197-5

12. Harris, C. M.; Piersol, A. G., 2002: Harris' shock and vibration handbook. McGRAW-Hill, New York, 1451 pp.

13. Il'gamov, M. A.; Khakimov, A. G., 2009: Diagnosis of damage of a cantilever beam with a notch. Russian Journal of Nondestructive Testing, 45(6): 430-435. http:// dx.doi.org/10.1134/S1061830909060072

14. ISO, 1975: International Standard 3129. Wood - Sampling Methods and General Requirements for Physical and Mechanical Tests.

15. Jang, S. K.; Bert, C. W., 1989: Free vibration of stepped beams: exact and numerical solutions. Journal of Sound and Vibration, 130: 342-346. http://dx.doi.org/10.1016/ 0022-460X(89)90561-0

16. Lee, K. T., 2008: Vibration of two cantilever beams clamped at one end and connected by a rigid body at the other. Journal of Mechanical Science and Technology, 23: 358-371. http://dx.doi.org/10.1007/s12206-008$1008-2$ 
17. Leonard, F.; Lanteigne, J.; Lalonde, S.; Turcotte, Y., 2000: Free-vibration behaviour of a cracked cantilever beam and crack detection. Mechanical Systems and Signal Processing, 15(3): 529-548. http://dx.doi.org/10.1006/ mssp.2000.1337

18. Madhoushi, M.; Hashemi, S. M.; Behzad, M., 2008: Evaluation of influence of decay on dynamic and static moduli of elasticity in Iranain beech by using of NDT stress wave (in Persian). Journal of Agriculture Science and Natural Resources, 15(3): 1-9.

19. Negahban, D., 1999: Vibrations of cantilever beams: deflection, frequency and research uses. http://em-ntserver. unl.edu/Mechanics-Pages/Scott-Whitney/325hweb/. (4 Feb 2009).

20. Orhan, S., 2007: Analysis of free and forced vibration of a cracked cantilever beam. NDT\&E international, 40: 443-450. http://dx.doi.org/10.1016/j.ndteint.2007.01.010

21. Radhakrishnan, V. M., 2004: Response of a cracked cantilever beam to free and forced vibrations. Defense Science Journal, 54(1): 31-38.

22. Roohnia, M.; Bremaud, I.; Guibal, D.; Manouchehri, N., 2006: NDT-LAB; Software to evaluate the mechanical properties of wood. Pages 213-218 in M Fioravanti and $\mathrm{N}$ Macchioni, eds Proc International Conference on Integrated Approach to Wood Structure Behaviour and Applications - Joint meeting of ESWM and Cost Action E35, 15-17 May, Florence - Italy, DISTAF - University of Florence.

23. Roohnia, M.; Tajdini, A., 2008: Investigation on the Possibility of Modulus Elasticity and Damping Factor Measurements, in timbers from Arizona cypress Using Free Vibration NDT in Comparison with Static Bending and Forced Vibration NDT (in Persian). Journal of agricultural science, 13(4): 1017-1027.

24. Roohnia, M.; Yavari, A.; Tajdini, A., 2010: Elastic parameters of poplar wood with end-cracks. Annals of Forest Science, 67(4): 409p1-409p9.
25. Roohnia, M.; Alavi-Tabar, S. E.; Hossein, M. A.; Brancheriau, L.; Tajdini, A., 2011a: Dynamic modulus of elasticity of drilled wooden beams. Nondestructive Testing and Evaluation, 26(2): 141-153. http://dx.doi.org/10. 1080/10589759.2010.533175

26. Roohnia, M.; Shafiee, P.; Manouchehri, N., 2011b: Fixed-free against free-free beams for dynamic Young's modulus of wood. Proceedings of the $17^{\text {th }}$ international wood-ndt symposium. Sopron, Hungary.

27. Rossi, R. E.; Laura, P. A. A., 1990: A note on transverse vibrations of a Timoshenko beam of nonuniform thickness clamped at one end and carrying a concentrated mass at the other. Journal of Sound and Vibration, 143(3): 491-502. http://dx.doi.org/10.1016/0022-460X(90)90738-L

28. Shafiee, P., 2010: Designing a System to Evaluate the Modulus of Elasticity of Wood Using Free Vibration on a Cantilever Beam (in Persian). MSc thesis, Supervised by Roohnia M, Islamic Azad University, Karaj Branch, Iran.

29. Turk, C.; Hunt, J.; Marr, D. J., 2008: Cantilever-beam dynamic modulus for wood composite products: Part 1 Apparatus. United States Department of Agriculture Forest Service - Forest Products Laboratory - Research Note FPL-RN-0308.

30. Yu, S. D., 2009: Free and forced flexural vibration analysis of cantilever plates with attached point mass. Journal of Sound and Vibration. 321: 270-285. http://dx.doi. org/10.1016/j.jsv.2008.09.042

\section{Corresponding address:}

Associate Professor MEHRAN ROOHNIA, Ph.D.

Karaj Branch, Islamic Azad University,

Shahid Moazen BLVD.

P. O. Box: 31485-313

Rajaee-shahr, KARAJ - IRAN

e-mail: mehran.roohnia@kiau.ac.ir 